Reprinted with permission from: Plant Disease. 1993. 77:319.

Published and copyrighted by: American Phytopathological Society, APS Press. http://www.apsnet.org

\title{
Pathogens of leafy spurge in Inner Mongolia, China
}

\author{
S.-M. YANG, J.-Y. ZHUANG, and W. J. LIU \\ Yang is with the USDA-ARS, Foreign Disease-Weed Science Research Unit, Fort Detrick, Frederick, MD 21702; \\ Zhuang is with the Systemic Mycology and Lichenology Laboratory, Academia Sinica, Beijing, China; and Liu is with \\ the Biological Control Laboratory, CAAS, Beijing, China. Plant Dis. 77:319, 1993.
}

Surveys of pathogens on leafy spurge (Euphorbia esula L.) in Inner Mongolia, China, were conducted in 1989 and 1990. Fungi other than a powdery mildew and rusts were isolated on potato-dextrose agar amended with penicillin $\mathrm{G}$ and streptomycin sulfate. Pathogenicity of isolated fungi was determined by placing an agar block with mycelium on intact leaves of E. esula or by placing wheat kernels infested with mycelium at the crown of greenhouse-grown E. esula and covering the kernals with soil. Alternaria alternata(Fr.:Fr.) Keissl., Fusarium sp., Myrothecium verrucaria (Albertini and Schwein.) Ditmar:Fr., and Rhizoctonia sp. were pathogenic to E. esula. Pathogenicity of Erysiphe sp. was confirmed by inoculating E. esula with conidia. Melampsora euphorbiae Castagne, Uromyces kalmusii Sacc., U. striatellus Tranz., and U. striatus Schröt. were found on E. esula. Pathogenicity of U. striatus was confirmed by infection of Medicago sp. with aeciospores found on leafy spurge, but pathogenicity of the other three rust pathogens has not been determined. This is the first report of $U$. kalmusii on E. esula in Inner Mongolia and of $U$. striatellus on E. esula in China.

\footnotetext{
${ }^{1}$ Accepted for publication 18 November 1992.
} 